A 20-min sample was included in the combined test to allow comparison with the releasing hormone test procedure as previously published (Besser et al., 1972; Hall et al., 1972). The data for TSH responses to TRH (Anderson et al., 1971) and $\mathrm{LH}$ responses to $\mathrm{LH} / \mathrm{FSH}-\mathrm{RH}$ (Besser et al., 1972), however, show that peak levels of these hormones persist up to $40 \mathrm{~min}$ after injection. Thus a sample at $30 \mathrm{~min}$ would show the peak equally well, and the 20-min sample could be omitted for routine use of the combined test. Prolactin was not measured in these subjects, but the combined test may also prove useful for assessment of pituitary prolactin secretion, for serum levels of this hormone are known to be increased by TRH (Bowers $e t$ al., 1971; Jacobs et al., 1971; L'Hermite et al., 1972).

It is proposed that anterior pituitary function can be assessed in a single combined test, which is convenient and time saving and can be performed on outpatients.

Our thanks are due to Miss M. Tooley and Miss P. Heyma for their skilled technical help. The hypothalamic hormones were supplied by Dr. W. Bogie of Hoechst, U.K. The LH and FSH for iodination were supplied by Dr. A. S. Hartree and Dr. W. R. Butt, and reagents for the immunoassays by the National Pituitary Agency and the Medical Research Council.

Requests for reprints should be addressed to: Dr. P. Harsoulis, The Endocrine Unit, Department of Medicine, Royal Postgraduate Medical School, Ducane Road, London W12 0HS.

\section{References}

Anderson, M. S., et al. (1971). New England fournal of Medicine, 285, 1279.
Beardwell, C. G., Burke, C. W., and Cope, C. L. (1968). Fournal of Endocrinology, 42, 79.

Besser, G. M., Ratcliffe, J. G., Kilborn, J. R., Ormston, B. J., and Hall, R. (1971). Fournal of Endocrinology, 51, 699 .

Besser, G. M., et al. (1972). British Medical fournal, 3, 267.

Bowers, C. Y., Friesen, H. G., Hwang, P., Guyda, H. J., and Folkers, K. (1971). Biochemical and Biophysical Research Communications, 45, 1033. Fleischer, N., Burgus, R., Vale, W., Dunn, T., and Guillemin, R. (1970). fournal of Clinical Endocrinology and Metabolism, 31, 109.

Greenwood, F. C., Landon, J., and Stamp, T. C. B. (1966). Fournal of Clinical Investigation, 45, 429.

Gual, C., Kastin, A. J., and Schally, A. V. (1972). Recent Progress in Hormone Research, 28, 173 .

Haigler, D. E., Pittman, J. A., Hershman, J. M., and Baugh, C. M. (1971). Journal of Clinical Endocrinology and Metabolism, 33, 573.

Hall, R., Ormston, B. J., Besser, G. M., Cryer, R. J., and McKendrick, M. (1972). Lancet, 1, 759 .

Hartog, M., Gaafar, M. A., Meisser, B., and Fraser, T. R. (1964). British Medical fournal, 2, 1229.

Jacobs, L. S., Snyder, P. J., Wilber, J. F., Utiger, R. D., and Daughaday, W. H. (1971). Fournal of Clinical Endocrinology and Metabolism, 33,996. Karlberg, B., Almquist, S., and Werner, S. (1971). Acta Endocrinologica (Copenhagen), 67, 288.

Kastin, A. J., Schally, A. V., Gonzales-Barcena, D., Schalch, D. S., Lee, L., and Villalpando, S. (1971). Clinical Research, 19, 374.

Kastin, A. J., Gual, C., and Schally, A. V. (1972). Recent Progress in Hormone Research, 28, 201.

L'Hermite, M., et al. (1972). Lancet, 1, 763.

Marshall, J. C., et al. (1972 a). British Medical fournal, 4, 643.

Marshall, J. C., Anderson, D. C., Burke, C. W., Galvao-Teles, A., and Fraser, T. R. (1972 b). Journal of Endocrinology, 53, 261.

Marshall, J. C., Anderson, D. C., Fraser, T. R., and Harsoulis, P. (1973). fournal of Endocrinology, 56, 431.

Nillius, S. J., and Wide, L. (1972). Fournal of Obstetrics and Gynaecology of the British Commonwealth, 79, 865.

Ormston, B. J., Kilborn, J. R., Garry, R., Amos, J., and Hall, R. (1971). British Medical fournal, 2, 199.

Rothenbuchner, G., et al. (1971). European fournal of Clinical Investigation, $1,389$.

Yen, S. C. C., et al. (1972). Fournal of Clinical Endocrinology and Metabolism 34, 1108.

\title{
Lipoid Pneumonia in Infants and Children in South India
}

\author{
S. BALAKRISHNAN
}

British Medical fournal, 1973, 4, 329-331

\section{Summary}

Oil-aspiration pneumonia is a common cause of mortality and morbidity in infants and young children in South India. The high incidence of this condition results from the local custom of giving oil baths to infants and of cleansing the mouth, throat, and nose with oil. The clinical findings in 12 cases, 10 of them in babies aged under 8 months, are described. The signs range from an acute segmental collapse of the lung, clearing in a few days, to a chronic picture mimicking pulmonary tuberculosis or mucoviscoidosis. Mothers in South India should be advised to abandon the practice of cleansing their baby's mouth and nose with oil.

\section{Introduction}

The aspiration of fatty substances, particularly milk, into the bronchi and alveoli is one of the principal causes of bronchopneumonia in the first months of life (Bromer and Wolman, 1939; Caffey, 1967), especially in premature babies, marasmic infants, and in children whose cough reflex has been de\footnotetext{
Department of Paediatrics, Jawaharlal Institute of Postgraduate
Medical Education and Research, Pondicherry-6, India

S BALAKRISHNAN, M.B., F.R.C.P.(C), Professor of Paediatrics
}

pressed. This paper reports 12 cases of lipoid pneumonia in infants and young children resulting from a local practice in Pondicherry, South India, of giving babies oil baths and of using oil to cleanse their mouths and nasal passages. It is a cause of much morbidity and mortality in the first few years of life.

\section{Clinical Features}

The patients comprised 10 infants ( 6 boys and 4 girls), aged from 23 days to 8 months, and a boy and a girl, aged 2 and 3 years respectively, who were among the cases of bronchopneumonia or suspected pulmonary tuberculosis admitted to the Jipmer Hospital, Jawaharlal Institute of Postgraduate Medical Education and Research, and to the State Government General Hospital, Pondicherry, from May 1971 to September 1972.

The history in each case was of the child having been given an oil bath. This practice often includes "oil cleansing" of the throat, eyes, nose, and ears by the mother or grandmother or by a skilled woman whose services are specially sought for the purpose. A half-spoonful or more of gingilli oil is placed in the baby's mouth and repeatedly smeared on the tongue "to remove the white coating." The woman then blows through the child's mouth in order to flush the secretions out through the nose. This practice is often started as early as the fifth day. Gingilli oil is also applied to the eyes and ears and occasionally put into the nostrils. Should the baby at any time have an illness an oil bath is given on 
recovery. The bath is repeated on alternate days for up to three months and then once weekly or fortnighly for up to 12 to 18 manths "until the child is walking about."

In the 10 acute cases the interval between the oil bath and the onset of symptoms was one day in five infants and from two to five days in another five. A history of chronic illness was given in the cases of the two older children. The symptoms had been present for one day or less before admission to hospital in five of the acute cases and for two to seven days in four others. In one case they had been present for 10 days. They had been present for 18 months and 30 months respectively in the cases of the two older children.

The main presenting symptoms on admission to hospital are shown in table I. Chest radiographs showed that the pulmonary lesions were commoner in the upper and middle lobes of the right lung than elsewhere (table II, figs. 1 and 2). In no case was the left lung only affected. Pleural effusion or pneumocysts were not seen on $x$-ray examination in any of the cases. The results of other investigations are shown in table III.
TABLE II-Nature and Situation of Pulmonary Lesions seen on Radiographs

\begin{tabular}{|c|c|c|c|c|c|c|}
\hline \multirow{2}{*}{ Lesion } & \multicolumn{3}{|c|}{ Right Lung } & \multicolumn{2}{|c|}{ Left Lung } & \multirow{2}{*}{$\begin{array}{l}\text { Both } \\
\text { Lungs }\end{array}$} \\
\hline & $\begin{array}{l}\text { Upper } \\
\text { Lobe }\end{array}$ & $\begin{array}{c}\text { Middle } \\
\text { Lobe }\end{array}$ & $\begin{array}{c}\text { Lower } \\
\text { Lobe }\end{array}$ & $\begin{array}{l}\text { Upper } \\
\text { Lobe }\end{array}$ & $\begin{array}{c}\text { Lower } \\
\text { Lobe }\end{array}$ & \\
\hline $\begin{array}{l}\text { Collapse } \ldots \\
\text { Emphysema (obstructive) } \\
\text { Interstitial pneumonitis } \\
\text { Batwing oedema }\end{array}$ & $\frac{4^{*}}{2}$ & $\begin{array}{l}3+ \\
\frac{1}{-}\end{array}$ & $\frac{3}{1}$ & $\frac{-}{3}$ & $\bar{z}$ & $\begin{array}{l}5 \\
1\end{array}$ \\
\hline
\end{tabular}

* In two cases the collapse was apical and posterior.

+ In two cases the collapse was associated with collapse of upper lobe.

TABLE III-Results of Relevant Investigations

\begin{tabular}{|c|c|c|c|}
\hline Investigation & & No. of Cases & Result \\
\hline $\begin{array}{l}\text { Mantoux test (1 T.U.) } \\
\text { Mantoux test (5 T.U.) } \\
\text { Pleural aspiration. } \\
\text { Radio-opaque swallow } \\
\text { Sweat electrolytes } \\
\text { Bronchoscopy aspirate } \\
\text { Lung biopsy }\end{array}$ & $\begin{array}{ll}. & \cdots \\
\cdots & \cdots \\
\cdots & \cdots \\
\cdots & \cdots \\
\cdots & \cdots\end{array}$ & $\begin{array}{r}12 \\
2 \\
1 \\
1 \\
1 \\
1 \\
2\end{array}$ & $\begin{array}{l}\text { Negative } \\
\text { Negative } \\
\text { Dry } \\
\text { No tracheo-oesophageal fistula } \\
\text { Normal } \\
\text { Ether extract positive for oil } \\
\text { Case } 1 \text { : interstitial cellular } \\
\text { infiltration with partial } \\
\text { alveolar collapse. Foamy } \\
\text { macrophages filling alveoli } \\
\text { and infiltrating interstitium } \\
\text { of bronchiole (fig. } 3 \text { ) } \\
\text { Case } 2: \text { macrophages present; } \\
\text { no polymorphs or } \\
\text { lymphocytes }\end{array}$ \\
\hline
\end{tabular}

The physical signs on examination of the chest conformed with the radiological findings. In acute cases with collapse of

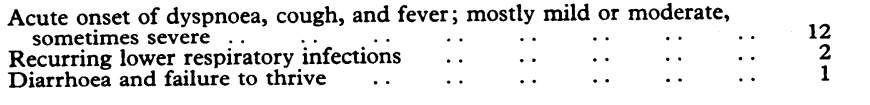
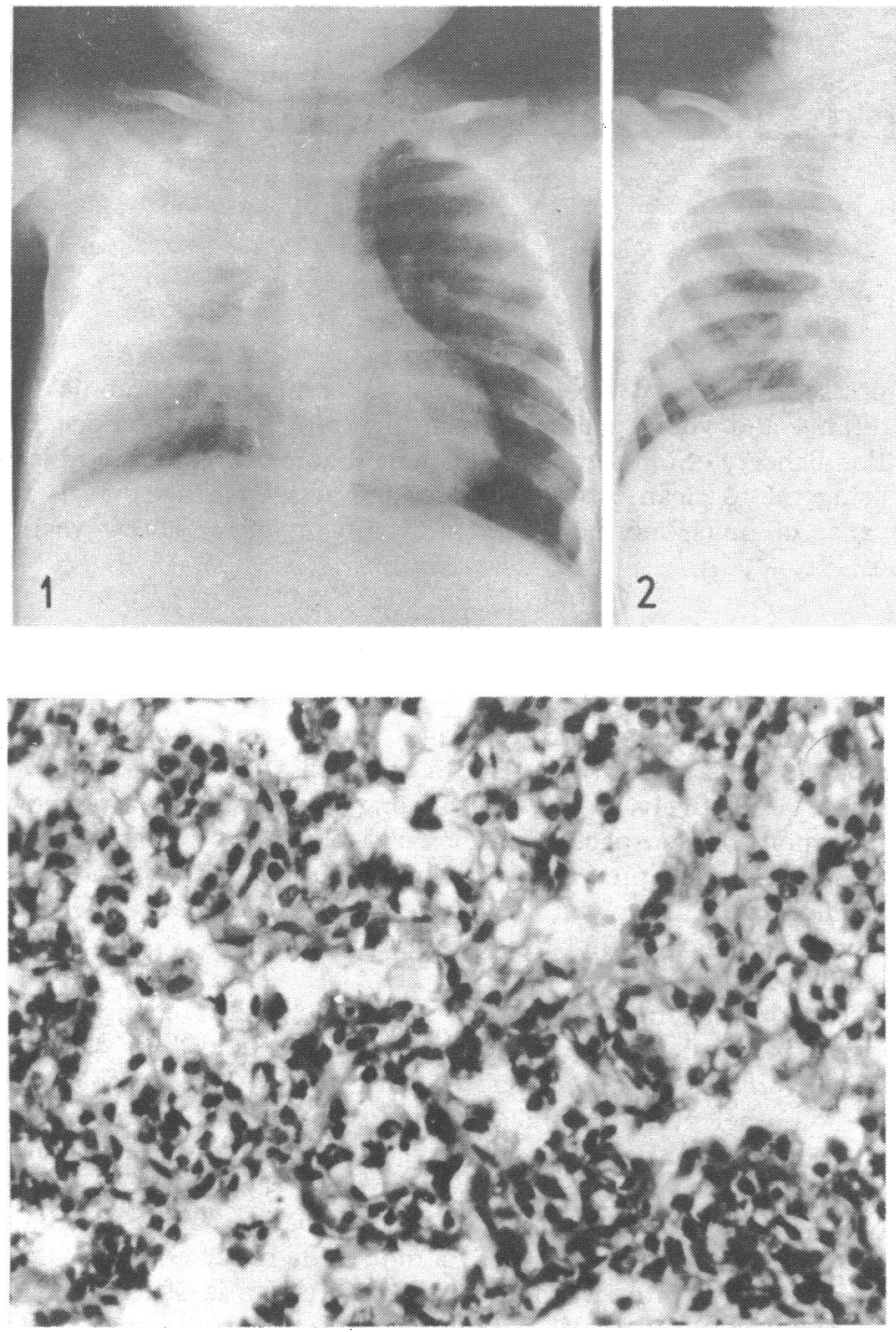

FIG. 3-Lung biopsy showing interstitial pneumonitis, partial alveolar collapse, and infiltration with foamy macrophages. (Haematoxylin-eosin $\times$ 400.) the lung, collapse-consolidation, and obstructive emphysema there were dullness and diminished air entry or sometimes bronchial breathing. Scattered fine to medium crepitations were nearly always present and were sometimes the only feature other than dyspnoea. Wheezing and rhonchi were notably absent in the severe cases. Fine rhonchi were occasionally heard after a few days. In the chronic cases wheezing and rhonchi were episodically present. They were taken to be the result of an intercurrent secondary infection or one seeded by further oil inhalation.

\section{Treatment}

The details of antibiotic and supportive therapy, such as the administration of humidified oxygen, of the patients are omitted. Bronchoscopic aspiration was attempted in some cases but without positive benefit. While this procedure was indicated in early cases and cases of obstruction of the larger airways, postural drainage after the administration of bronchodilator drugs was resorted to in cases of distal airway 
obstruction. One 2-year-old child, who had been ill for 18 months and had extensive chronic interstitial pneumonitis of both lungs, was given corticosteroid therapy for two months with no improvement. This accorded with other reports that corticosteroids in the treatment of lipoid and hydrocarbon pneumonia did not reduce morbidity or mortality (Graham, 1956; Verhulst and Page, 1961).

\section{Discussion}

The diagnosis of oil-aspiration pneumonia in these patients was well established. They belonged to the most susceptible age group. The two older children had been subjerted to oil baths since early infancy. The sudden onset of respiratory symptoms after known inhalation of gingilli oil, often forcefully blown in, the radiological findings of airway obstruction, and the presence of acute or chronic interstitial pneumonitis were typical of the condition. In two cases the diagnosis was proved by aspiration biopsy of the lung (Nathanson et al. . 1943) and in one by examination of the bronchoscopic aspirate. Investigations excluded other possible diagnoses.

The two older patients were followed for one and two years respectively, and from the biopsy and other findings in these and the acute cases a summary of the evolution of oil-aspiration pneumonia may be given. At first there is an acute interstitial pneumonitis shown radiologically by heavy peribronchial striae; scattered, small, round peribronchial densities; patchy emphysema; and enlarged hilar shadows. These are sometimes preceded by a transient batwing oedema and are often associated with segmental or lobar obstructive lesions, usually atelectasis or rarely emohysema. The next stage is one of diffuse granulomatous inflammation, showing in the $x$-ray film as dense and widened hilar and perihilar shadows, heavy and broad bronchovascular markings, sometimes with reticular confluences, and often with scattered round densities of varying sizes (fig. 2). Finally, there is a progressive widening and hardening of the linear sbadows and round densties with the formation of multiple nodulesthe foreign-body oil granuloma or paraffinoma seen in adults (Ikeda, 1937). One such, surgically removed, has been reported in an infant aged 3 months, who was forcibly fed a teaspoon of ghee or burnt butter daily for about a fortnight from the age of 1 month (Bakshi et al., 1971) and another in an infan aged 34 weeks (Brimblecombe, et al., 1951).

The incidence of staphylococcal and other purulent pneumonia is high in Pondicherry compared with, say, New Delhi, and apant from the climate, which is more humid, an important contributory factor is no doubt the mixture of oil and infection inspired by infants during the customary oil baths. Inquiry among a random sample of 500 mothers attending the paediatric outpatient department of the Jipmer Hospital showed that $20 \%$ of them had stanted oil baths for their babies on the fifth day, that $95 \%$ were still giving the baths after three months, and that in about $20 \%$ of cases oil was put into the baby's throat and mouth-to-mouth blowing carried out. The custom is also prevalent in the states of Tamil Nadu (Madras), Karnataka (Mysore), and Kerala.

Aspiration pneumonia is probably the commonest cause of bilateral emphysema in the early months of life (Caffey, 1967). Adams (1967) warned that substances such as codliver-oil, castor oil, and mineral oil are easily aspirated even when carefully administered. Eichenwald and McCracken (1969) stated that intranasal medication in an oily vehicle should never be given. The oil bath as practised by older children and adults in India has many virtues, but mothers should be told that oil should never be put into the mouth or nose of a baby or young child.

\section{References}

Adams, W. C. (1967). In Disorders of the Respiratory Tract in Children, ed. E. L. Kendig, iun., 1st edn., p. 349. Philadelphia, Saunders

Bakshi, S., Bhakoo, O. N., Singh, S., and Bannerjee, A. K. (1971). Indian Pediatrics, 8, 793

Brimblecombe, F. S. W., Crome, L., and Tizard, J. P. M. (1951). Archives of Disease in Childhood, 25, 141

Bromer, R. S., and Wolman, I. (1939). Radiology, 32, 1.

Caffey, J. (1967). Pediatric X-ray Diagnosis, 5th edn., p. 258. Chicago, Year Book Medical Publishers.

Eichenwald, H. F., and McCracken, G. H., jun. (1969). In Text Book of Pediatrics, ed. W. E. Nelson, 9th edn., p. 927. Philadelphia, Saunders.
P.

Graham, J. R. (1956). Transactions of the American Clinical and Climatological Association, 67, 104.

Ikeda, K. (1937). Archives of Pathology, 23, 470.

Nathanson, L., Frenkel, D., and Jacobi, M. (1943). Archives of Internal Medicine, $72,627$.

Verhulst, H. L., and Page, L. A. (1961). Journal of New Drugs, 1, 147. 